\title{
Protective effect of silymarin and ascorbic acid in valproic acid-induced hepatic toxicity in male albino Rats
}

\author{
Mahrous A Ibrahim, Rehab I Abdel-Karim, Hany G Tamam, Alaa A Mohamed, \\ Farooq A Wani
}

\begin{tabular}{|c|c|}
\hline & ABSTRACT \\
\hline $\begin{array}{l}\text { KEYWORDS } \\
\text { Valproic acid, } \\
\text { Silymarin, } \\
\text { Ascorbic acid, } \\
\text { Hepatoxicity, } \\
\text { Antioxidants }\end{array}$ & $\begin{array}{l}\text { Valproic acid (VPA) is widely used worldwide for the treatment of epilepsy, } \\
\text { migraine and as a mood stabilizer in some psychiatric diseases. It has been condemned } \\
\text { for causing hepatotoxicity. Oxidative stress and some metabolites of VPA have been } \\
\text { proposed to be responsible for VPA induced hepatotoxicity. The current study was } \\
\text { conducted to assess the damage induced by toxic doses of valproic acid on rats' livers and } \\
\text { to assess the protective role of silymarin and ascorbic acid in VPA induced } \\
\text { hepatotoxicity. Forty-two male albino rats were divided equally into seven groups; group } \\
\text { (1): normal control, group (2): ascorbic acid, group (3): silymarin, group (4): VPA, } \\
\text { group (5): VPA+ascorbic acid, group (6): VPA + silymarin and group (7): VPA + } \\
\text { ascorbic acid + silymarin. After four weeks, the animals were sacrificed and livers were } \\
\text { collected for histopathologic examination and biochemical assessment. VPA group } \\
\text { showed a significant increase in serum alanine aminotransferase, aspartate } \\
\text { aminotransferase, alkaline phosphatase, bilirubin and a significant decrease in albumin } \\
\text { and total protein. Liver malondialdehyde was significantly increased and antioxidant } \\
\text { enzymes levels were significantly decreased. Liver sections showed loss of normal pattern } \\
\text { of hepatocytes, inflammatory infiltration, congested central vein and fatty infiltration. } \\
\text { Each of ascorbic acid and silymarin partially improved some of the measured } \\
\text { parameters. When they were combined together, they depict high improvement in most } \\
\text { of measured parameters and showed near normal liver sections. This study concludes } \\
\text { that combination of ascorbic acid and silymarin has synergistic antioxidant and } \\
\text { hepatoprotective effects against VPA induced toxic effects on liver. }\end{array}$ \\
\hline
\end{tabular}

\section{Introduction}

Sodium valproate is the salt of valproic acid (VPA). It is an eight carbon branched chain fatty acid, this structure allows its

\footnotetext{
Mahrous A Ibrahim

Forensic Medicine and Clinical Toxicology Department, Faculty of Medicine, Suez Canal University (SCU), Ismailia, Egypt.

Forensic Medicine and Clinical Toxicology Department, College of Medicine, Aljouf University, Aljouf, KSA.

Rehab I Abdel-Karim

Forensic Medicine and Clinical Toxicology Department, Faculty of Medicine, Suez Canal University (SCU), Ismailia, Egypt.

Email: rehabnegm@yahoo.com

Hany $G$ Tamam

Forensic Medicine and Clinical Toxicology Department, Faculty of Medicine, AlAzhar University, Cairo, Egypt.

Alaa A Mohamed

Medical Biochemistry Department, Faculty of Medicine, BeniSuef University, Beni- Suef, Egypt.

Pathology Department, Faculty of Medicine, Aljouf University, Aljouf, KSA.

Farooq A Wani

Pathology Department, Faculty of Medicine, Aljouf University, Aljouf, KSA.
}

interaction with cell membrane facilitating its therapeutic and toxic actions (Al-Rouby and Gawish, 2013). Valproic acid is a worldwide used anticonvulsant drug. It is mainly used for the treatment of epilepsy (Perucca, 2002). Furthermore, it is used for the treatment of migraine and also used as a mood stabilizer in many psychiatric diseases such as bipolar disorder (Rosenberg, 2007).

The major pathways responsible for VPA metabolism are; cytochrome $\mathrm{P} 450$ oxidation, glucuronic acid conjugation and $\beta$-oxidation and omega $(\omega)$ oxidation (Silva et al., 2008). These metabolic pathways are associated with hepatotoxicity due to increased synthesis of unsaturated valproic acid derivatives and depletion of $\beta$-oxidation machinery (Perucca, 2002; Kiang et al., 2010). Some VPA metabolites like "4-ene VPA and 2,4-diene 
VPA" have been reported to be responsible for hepatotoxicity (Kesterson et al., 1984). Nephrotoxicity (Amrani et al., 2016), impaired fertility (Khan et al., 2011) and teratogenicity (Tung and Winn, 2011) have also been reported.

Valproic acid induced hepatotoxicity can be mild and associated with elevated liver enzymes which usually become normalized after the drug cessation. Unfortunately VPA might lead to a fatal type of hepatotoxicity which occurs due to idiosyncratic reaction and shows hepatic microvesicularsteatosis and necrosis (Tong et al., 2005). The exact mechanism by which VPA induces hepatotoxicity is not fully explained. Oxidative stress resulting from the increased production of reactive oxygen species (ROS) and free radicals has been postulated to be responsible for VPA induced hepatotoxicity (Tong et al., 2005; Kiang et al., 2010). Altered glutathione (GSH) homeostasis through depletion of GSH stores was reported to be involved in aggravating VPA induced hepatotoxicity (Jurima-Romet et al., 1996). Furthermore, Pourahmad et al. (2012) and Sokmen et al. (2012) reported the depletion of hepatocyte glutathione (GSH) stores in rats given VPA. As oxidative stress appeared to assume a major role in VPA induced hepatotoxicity, several natural substances have been used to reduce the hepatic damage caused by oxidative stress induced by VPA depending on their antioxidant activity and their competence to scavenge free radicals (Jurima-Romet et al., 1996; Sokmen et al., 2012; Abdella et al., 2014).

Silymarin is an important flavonoid extracted from a plant named milk thistle (Silybummarianum). Silymarin has been used worldwide as a "liver support" natural product and it was effective in improving the clinical condition of patients with acute hepatitis (El-
Kamary et al., 2009). Silymarin has an antioxidant effect as it is considered a powerful free radicals scavenger (Najafzadeh et al., 2010). Silymarin has also shown antiinflammatory and anti-carcinogenic action in mice (Kaur and Agarwal, 2007), hepatoprotective action against carbon tetrachloride (CC14) (Yadav et al., 2008), arsenic (Jain et al., 2011) and acetaminophen (Bektur et al., 2016) toxicity.

Ascorbic acid (vitamin C) is a hydrophilic natural product that exerts antioxidant activity (Xavier et al., 2007) through donating electrons to different types of free radicals (Adikwu and Deo, 2013). Citrus, green leafy vegetables, liver and kidney are the natural sources of this vitamin (Stangeland et al., 2009). It has shown hepatoprotective effects against oxidative stress caused by several substances such as isoniazid (Ergul et al., 2010)and acetaminophen (Sabiu et al., 2015) toxicity.

This study aims to assess the postulated protective and the antioxidant effects of silymarin and ascorbic acid in valproic acidinduced hepatic toxicity in male albino rats.

\section{Material and Methods}

\section{Chemicals}

Sodium valproate was purchased from pharmacy in the form of tablets with trade name Depakine (SanofiSynthelabo, France), each containing $200 \mathrm{mg}$ of sodium valproate. Vitamin C: was purchased from pharmacy in the form of tablets, each containing $500 \mathrm{mg}$ of ascorbic acid (Kahira Pharma Co., Egypt). Silymarin: was obtained from SEDICO Pharmaceutical Company in the form of sachets; each contains $140 \mathrm{mg}$ of silymarin. All other chemicals and diagnostic kits were obtained from Sigma (St. Louis, MO, USA). 


\section{Animals and experimental design}

Forty-two adult male albino rats, weighting $190.25 \pm 6.22 \mathrm{~g}$ at the beginning of the experiment, were obtained from Faculty of Veterinary Medicine, Suez Canal University. They were fed a standard commercial diet (ATMID Company, Egypt) and allowed to drink water ad labitum. After one week of adaptation in small cages in a room with good ventilation and controlled temperature $(24 \pm 2$ $\left.{ }^{\circ} \mathrm{C}\right)$ and lighting (12-h light: 12-h dark).Furthermore, the anesthetic procedures and handling of animals was carried out according to The European Communities Council Directive of 1986 (EC 86/609) and complied with the ethical guidelines of College of Medicine Ethical Committee, Suez Canal University.

The rats were divided into seven groups; six rats each and the initial body weight of each rat was obtained before administration of the drugs:

- G1: rats served as negative control group that received only distilled water.

- G2: rats received ascorbic acid $200 \mathrm{mg} / \mathrm{kg}$ (dissolved in distilled water) according to Wu et al. (2015).

- G3: rats received silymarin $50 \mathrm{mg} / \mathrm{kg}$ (dissolved in distilled water) according to Girish et al. (2009).

- G4: rats received valproic acid $300 \mathrm{mg} / \mathrm{kg}$ (dissolved in distilled water) with reference to thedose range of hepatotoxicity (Tong et al., 2005).

- G5: rats received valproic acid $300 \mathrm{mg} / \mathrm{kg}$ and ascorbic acid $200 \mathrm{mg} / \mathrm{kg}$.

- G6: rats received valproic acid $300 \mathrm{mg} / \mathrm{kg}$ and silymarin $50 \mathrm{mg} / \mathrm{kg}$.

- G7: rats received valproic acid $300 \mathrm{mg} / \mathrm{kg}$, ascorbic acid $200 \mathrm{mg} / \mathrm{kg}$ andsilymarin 50 $\mathrm{mg} / \mathrm{kg}$.

All drugs were given orally by orogastric gavage once daily for 28 days.
At the end of experiment, the final body weight was obtained for each rat and the relative body weight (RBW) was calculated as; $\mathrm{RBW}=$ (final body weight / initial body weight) $x$ 100. Control and treated groups were fasting overnight before being sacrificed under ether inhalation anesthesia one day after the last treatment. All animals were sacrificed between 8:00 and 10:00 am to avoid any possible diurnal variations in antioxidant enzyme level. Prior to being sacrificed, blood samples were collected, centrifuged and sera of the rats in different study groups were collected for biochemical tests. The liver of each rat was removed and weighted and the relative liver weight (RLL) was calculated as; RLL $==$ (liver weight / final body weight) x 100 .

\section{Measurement of liver function markers}

Serum alanine aminotransferase [ALT] $(\mathrm{U} / \mathrm{L})$ and aspartate aminotransferase [AST] (U/L) were determined by the method of Reitman \& Frankel (1957). Serum alkaline phosphatase [ALP] (U/L) was determined according to Bessey et al. (1946) and Lowry et al. (1951). Total proteins (g\%) were determined by the method of Kingsley (1942). Albumin ( $\mathrm{g} \%$ ) was determined by the method of Pinnell and Northam (1978). Bilirubin level in $\mathrm{mg} / 100 \mathrm{ml}$ was measured based on the method of Perry et al. (1986).

\section{Estimation of the markers of oxidative stress and antioxidants}

\section{Hepatic homogenate preparation}

One gram of hepatic tissue was taken from each rat. Solution of ice-cold $0.9 \% \mathrm{NaCl}$ was utilized to wash the hepatic tissue and then homogenized in $9 \mathrm{ml}$ ice cold phosphatebuffered saline (PBS) with $\mathrm{pH}$ 7.5. This homogenate was centrifuged for 15 minutes at 3000 r.p.m and the supernatant was gathered and kept into Epipendorff tubes and kept at - 
$80^{\circ} \mathrm{C}$ for further utilization (Fernandez-Botran et al., 2002).

\section{Hepatic malondialdehyde(MDA) estimation}

Hepatic level of malondialdehyde (MDA) was estimated according to Kei technique (Kei, 1978). Briefly, $0.67 \%$ 2- thiobarbituric acid (TBA) and 20\% trichloroacetic acid solution was blended with $0.2 \mathrm{~mL}$ supernatant of hepatic homogenate and heated for $30 \mathrm{~min}$ in a boiling water bath. The reaction of TBA with MDA formed a pink colored chromogen which is estimated spectrophotometrically at $532 \mathrm{~nm}$. The measured outcomes were presented as MDA mmol/g tissue.

\section{Hepatic glutathione (GSH) estimation}

Hepatic level of GSH was estimated according to Beutler et al. (1963) technique. Briefly, $10 \%$ trichloroacetic acid was used to make hepatic homogenate deproteinzation, and centrifuged for $10 \mathrm{~min}$ at $3500 \mathrm{rpm}$. $0.04 \%$ 5,5'- dithiobis 2- nitrobenzoic acid (DTNB) solution and $0.32 \mathrm{~mol} / 1$ disodium hydrogen phosphate was blended with $50 \mu$ l supernatant of the hepatic homogenate. The reaction of GSH and DTNB formed a yellow colored substance which is estimated spectrophotometrically at $412 \mathrm{~nm}$. The measured outcomes were presented as GSH $\mathrm{mmol} / \mathrm{g}$ tissue.

\section{Hepatic glutathione peroxidase (GPx) estimation}

Hepatic level of glutathione peroxidase (GPx) was estimated according to Lawrence \& Burk (1976) technique. This technique depends on estimating the oxidation ofnicotinamide adenine dinucleotide phosphate (NADPH) using hydrogen peroxide as the substrate. Absorbance was estimated for 5 minutes at 340 $\mathrm{nm}$, and $6.22 \times 10-3$ as a coefficient of extinction was utilized for calculation. The adjustments in the absorbance at $340 \mathrm{~nm}$ at $1 \mathrm{~min}$ interval for $5 \mathrm{~min}$ were registered spectrophotometrically. The measured outcomes were presented as $\mathrm{mmol} / \mathrm{g}$ tissue.

\section{Hepatic superoxide dismutase (SOD) estimation}

Hepatic homogenate activity of superoxide dismutase (SOD) was estimated according to Minami and Yoshikawa (1979) technique. This method is based on the production of superoxide anions by pyrogallol autoxidation, detection of produced superoxide anions by nitro blue tetrazolium (NBT) formazan color development and estimation of the amount of produced superoxide anions scavenged by SOD (the inhibitory level of formazan color development). The spectrophotometer is used to measure the increase in the absorbance for $5 \mathrm{~min}$ at $560 \mathrm{~nm}$. The measured outcomes were presented as $\mathrm{U} / \mathrm{g}$ tissue

\section{Measurement of hepatic catalase (CAT) activity}

The method of Aebi (1984) was used to determine the hepatic catalase (CAT) activity in tissue homogenates. The rate of $\mathrm{H}_{2} \mathrm{O}_{2}$ decomposition was followed by monitoring absorption at $240 \mathrm{~nm}$ in $50 \mathrm{mM}$ phosphate buffer, $\mathrm{pH} 7.0$, containing $10 \mathrm{mM} \mathrm{H}_{2} \mathrm{O}_{2}$. One unit of catalase activity is defined as the amount of enzyme required to decompose $1 \mu \mathrm{mol}$ of hydrogen peroxide in $1 \mathrm{~min}$. The measured outcomes were presented as $\mathrm{U} / \mathrm{g}$ tissue.

\section{Histopathological examination}

For histopathological evaluation, $10 \%$ formalin was used for fixation of the liver for $24 \mathrm{~h}$, and standard dehydration was done in ascending grades of ethyl alcohol (70, 80, 95, and $100 \%)$. Liver tissue samples were then cleared in xylene and embedded in paraffinwax. Sections $(5 \mu \mathrm{m})$ were cut in a microtome and stained with hematoxylin and eosin (H-E). The sections were then viewed and photographed (Bancroft et al., 1996). 


\section{Statistical analysis}

Statistical analysis was done using SPSS software, version 22 for windows (SPSS, Inc., Chicago, IL, USA). Numerical data obtained from the experiment were expressed as mean \pm standard deviation (SD). Number of rats per each group was stated in the table or figure legends. After ascertaining the homogeneity of variance between treatment groups by Bartlett's test and to analyze mean differences between experimental groups for each parameter separately, one way analysis of variance (ANOVA) followed by StudentNewman- Keuls test wereperformed. Values of $\mathrm{p} \leq 0.05$ were considered to be statistically significant.

\section{Results}

Effect of valproic acid (VPA), ascorbic acid and silymarin on body and liver weights:

Table 1 shows that after 4 weeks study period, both final and relative body weights (RBW) were significantly decreased in G4 (the group administered VPA) compared to G1, G2 and G3 (control group, the group given ascorbic acid and the group given silymarin respectively), $(\mathrm{p} \leq 0.05)$. After administration of ascorbic acid and silymarinwith VPA in G5, G6 and G7 (VPA+ ascorbic acid, VPA+ silymarin and VPA+ ascorbic acid + silymarin respectively), both final and RBW significantly increased compared to G4, however they remained significantly lower than G1, G2 and G3.

Liver weight and relative liver weight (RLW) were significantly increased in G4 compared to G1, G2 and G3 ( $\mathrm{p} \leq 0.05$ ). Ascorbic acid and silymarin significantly decreased liver weight and RLW in G5, G6 and G7 compared to G4 ( $\mathrm{p} \leq 0.05)$, however they remained significantly larger than G1, G2 and G3 except for G7 (Table 1).
Effect of valproic acid (VPA), ascorbic acid and silymarinonliver function parameters:

VPA administration in G4 significantly increased ALT, AST, ALP and bilirubin and significantly decreased albumin and total protein compared to $\mathrm{G} 1, \mathrm{G} 2$ and $\mathrm{G} 3$ ( $\mathrm{p} \leq 0.05$ ). In groups G5, G6, and G7 (VPA+ ascorbic acid, VPA+ silymarin and VPA+ ascorbic acid + silymarin respectively), all measured hepatic function parameters were improved significantly compared to G4. However, they remained significantly different from $\mathrm{G} 1, \mathrm{G} 2$, and G3 ( $\mathrm{p} \leq 0.05)$. An exception has been noticed in G7 regarding ALP, albumin and bilirubin as those parameters showed no significant difference compared to the negative control group (G1) $(\mathrm{p}>0.05)$ (Table 2).

Effect of valproic acid (VPA), ascorbic acid and silymarin on liver oxidative markers:

Table (3) showed that the antioxidant markers (CAT, SOD, GSH and GPx) levels significantly decreased in G4 compared to G1, G2 and G3, while MDA significantly increased compared to those groups $(\mathrm{p} \leq 0.05)$. After administration of ascorbic acid and silymarinwith VPA in G5, G6 and G7, the levels of these markers significantly improved compared to VPA group (G4) ( $\mathrm{p} \leq 0.05)$, however in G5 and G6 they remained significantly different from G1, G2 and G3. It was noticed that after giving ascorbic acid in combination with silymarin in G7, the levels of those markers were better improved and have no significant difference from the control group $(\mathrm{G} 1)(\mathrm{p}>0.05)$.

\section{Histopathological changes in all groups:}

Histopathological examination showed normal hepatic architecture in the negative control group, as well as the groups administered ascorbic acid and silymarin (Figure 1). 
The livers of the group of rats givenvalproic acid showed loss of normal radiating pattern of hepatocytes with some hepatocytes showing increased eosinophilia and degeneration. Mononuclear inflammatory cell infiltrate, enlarged kupffer cells, dilated and congested central veins with disarray of hepatocyteswere also seen. Some liver sections showed loss of normal hepatic architecture and accumulation of fat (hepatic steatosis) (Figure 2).

Livers of rats given valproic acid and ascorbic acid showed little feathery degeneration of some hepatocytes with few inflammatory cells (Figure $3 \mathrm{H}$ ). When valproic acid was given with silymarin, rats' livers showed near normal hepatic architecture, with few hepatocytes showing degeneration and few inflammatory cells (Figure 3I). Liver sections from the group given a combination of silymarin and ascorbic acid in rats treated with valproic acid showed normal histological structure of central vein (CV) and surrounding hepatocytes (Figure 3J).

Table (1): Effects of valproic acid, ascorbic acid, silymarin, and their combination, on body weight and liver weight of rats $(n=42)$.

\begin{tabular}{|c|c|c|c|c|c|c|c|}
\hline Parameters & $\begin{array}{c}\text { G1 } \\
(n=6)\end{array}$ & $\begin{array}{c}\mathbf{G 2} \\
(\mathrm{n}=6)\end{array}$ & $\begin{array}{c}\text { G3 } \\
(n=6)\end{array}$ & $\begin{array}{c}\mathbf{G 4} \\
(\mathrm{n}=6)\end{array}$ & $\begin{array}{c}\text { G5 } \\
(n=6)\end{array}$ & $\begin{array}{c}\text { G6 } \\
(n=6)\end{array}$ & $\begin{array}{c}\mathbf{G 7} \\
(\mathrm{n}=6)\end{array}$ \\
\hline Initial body weight (g) & $\begin{array}{c}190.25 \pm \\
6.22\end{array}$ & $\begin{array}{c}186.55 \pm \\
6.6\end{array}$ & $189.7 \pm 6.8$ & $\begin{array}{c}193.5 \pm \\
9.45\end{array}$ & $\begin{array}{c}187.38 \pm \\
7.6\end{array}$ & $\begin{array}{c}191.7 \pm \\
7.86\end{array}$ & $\begin{array}{c}194 \pm \\
9.2\end{array}$ \\
\hline Final body weight (g) & $\begin{array}{c}203.6 \pm \\
12.45\end{array}$ & $\begin{array}{c}202.12 \pm \\
11.88\end{array}$ & $\begin{array}{c}205.12 \pm \\
10.85\end{array}$ & $\begin{array}{l}130.66 \pm \\
15.40^{\mathrm{abc}}\end{array}$ & $\begin{array}{l}188.60 \pm \\
3.33^{\text {abcd }}\end{array}$ & $\begin{array}{c}190.65 \pm \\
5.70^{\text {abcd }}\end{array}$ & $\begin{array}{l}195.8 \pm \\
6.42^{\text {abcd }}\end{array}$ \\
\hline RBW & 107.02 & 108.35 & 108.12 & $67.52^{\mathrm{abc}}$ & $100.65^{\mathrm{abcd}}$ & $99.45^{\text {abcd }}$ & $100.93^{\mathrm{abcd}}$ \\
\hline Liver weight (g) & $8.88 \pm 0.2$ & $\begin{array}{c}8.95 \pm \\
0.55 \\
\end{array}$ & $\begin{array}{c}9.10 \pm \\
0.38 \\
\end{array}$ & $\begin{array}{l}12.85 \pm \\
0.48^{\mathrm{abc}}\end{array}$ & $\begin{array}{c}9.76 \pm \\
0.26^{\text {abcd }}\end{array}$ & $\begin{array}{c}9.6 \pm \\
0.48^{\text {abcd }}\end{array}$ & $\begin{array}{l}9.12 \pm \\
0.16^{\mathrm{d}}\end{array}$ \\
\hline RLW & 4.36 & 4.43 & 4.44 & $9.83^{\mathrm{abc}}$ & $5.17^{\text {abcd }}$ & $5.04^{\mathrm{abcd}}$ & $4.66^{\mathrm{d}}$ \\
\hline
\end{tabular}

Data are mean \pm standard deviation. G1: control, G2: ascorbic acid, G3: silymarin, G4: valproic acid; G5: valproic acid+ ascorbic acid; G6: valproic acid+ silymarin; G7: valproic acid+ sscorbic acid+ silymarin; RBW: relative body weight; RLW: relative liver weight; a: significant compared to the control (G1) group; b: significant compared to ascorbic acid (G2) group; c: significant compared to silymarin (G3) group; d: significant compared to valproic acid (G4) group. 
Table (2): Effects of valproic acid, ascorbic acid, silymarin, and their combination, on liver functions parameters of rats $(\mathrm{n}=42)$.

\begin{tabular}{|c|c|c|c|c|c|c|c|}
\hline Parameters & $\begin{array}{c}\text { G1 } \\
(n=6)\end{array}$ & $\begin{array}{c}G 2 \\
(n=6)\end{array}$ & $\begin{array}{c}\text { G3 } \\
(n=6)\end{array}$ & $\begin{array}{c}G 4 \\
(n=6)\end{array}$ & $\begin{array}{c}\text { G5 } \\
(n=6)\end{array}$ & $\begin{array}{c}\text { G6 } \\
(n=6) \\
\end{array}$ & $\begin{array}{c}\text { G7 } \\
(n=6)\end{array}$ \\
\hline ALT (U/L) & $\begin{array}{c}27.38 \pm \\
4.11\end{array}$ & $\begin{array}{c}26.88 \pm \\
2.12\end{array}$ & $\begin{array}{c}24.88 \pm \\
3.98\end{array}$ & $\begin{array}{l}93.0 \pm \\
4.56^{\mathrm{abc}}\end{array}$ & $\begin{array}{l}71.33 \pm \\
5.61^{\text {abcd }}\end{array}$ & $\begin{array}{l}67.33 \pm \\
3.88^{\text {abcd }}\end{array}$ & $\begin{array}{l}47.66 \pm \\
4.59^{\text {abcd }}\end{array}$ \\
\hline AST (U/L) & $\begin{array}{c}30.90 \pm \\
4.06 \\
\end{array}$ & $\begin{array}{c}28.73 \pm \\
3.12 \\
\end{array}$ & $\begin{array}{c}27.15 \pm \\
4.31 \\
\end{array}$ & $\begin{array}{c}98.0 \pm \\
4.15^{\mathrm{abc}} \\
\end{array}$ & $\begin{array}{c}78.0 \pm \\
4.34^{\mathrm{abcd}} \\
\end{array}$ & $\begin{array}{c}58.0 \pm \\
4.35^{\text {abcd }} \\
\end{array}$ & $\begin{array}{l}49.17 \pm \\
4.79^{\text {abcd }}\end{array}$ \\
\hline ALP (U/L) & $\begin{array}{c}152.66 \pm \\
8.6 \\
\end{array}$ & $\begin{array}{c}151.17 \pm \\
10.16 \\
\end{array}$ & $\begin{array}{c}149.50 \pm \\
9.73 \\
\end{array}$ & $\begin{array}{r}200.33 \pm \\
7.06^{\mathrm{abc}} \\
\end{array}$ & $\begin{array}{r}180.83 \pm \\
5.42^{\text {abcd }}\end{array}$ & $\begin{array}{l}165.50 \pm \\
3.27^{\text {abcd }}\end{array}$ & $\begin{array}{c}155.33 \pm \\
7.68^{\mathrm{d}} \\
\end{array}$ \\
\hline $\mathrm{TP}(\mathrm{g} / \mathrm{dl})$ & $\begin{array}{c}6.55 \pm \\
0.75\end{array}$ & $\begin{array}{c}6.63 \pm \\
0.74\end{array}$ & $\begin{array}{c}6.72 \pm \\
0.71\end{array}$ & $\begin{array}{l}4.55 \pm \\
0.50^{\mathrm{abc}} \\
\end{array}$ & $\begin{array}{c}5.07 \pm \\
0.37^{\mathrm{abcd}}\end{array}$ & $\begin{array}{c}5.55 \pm \\
0.26^{\text {abdd }}\end{array}$ & $\begin{array}{c}6.02 \pm \\
0.42^{\text {abcd }}\end{array}$ \\
\hline $\begin{array}{l}\text { Albumin } \\
(\mathrm{g} / \mathrm{dl})\end{array}$ & $\begin{array}{c}4.32 \pm \\
.38 \\
\end{array}$ & $\begin{array}{c}4.20 \pm \\
0.4 \\
\end{array}$ & $\begin{array}{c}4.43 \pm \\
0.41 \\
\end{array}$ & $\begin{array}{l}2.73 \pm \\
0.37^{\mathrm{abc}} \\
\end{array}$ & $\begin{array}{c}3.03 \pm \\
0.08^{\mathrm{abcd}}\end{array}$ & $\begin{array}{c}3.30 \pm \\
0.41^{\mathrm{abcd}} \\
\end{array}$ & $\begin{array}{l}3.93 \pm \\
0.16^{\mathrm{cd}} \\
\end{array}$ \\
\hline $\begin{array}{c}\text { Bilirubin } \\
(\mathrm{mg} / \mathrm{dl})\end{array}$ & $\begin{array}{c}0.27 \pm \\
.03\end{array}$ & $\begin{array}{c}0.25 \pm \\
.02\end{array}$ & $\begin{array}{c}0.25 \pm \\
0.03\end{array}$ & $\begin{array}{l}0.82 \pm \\
.08^{\mathrm{abc}}\end{array}$ & $\begin{array}{l}0.62 \pm \\
.06^{\text {abcd }}\end{array}$ & $\begin{array}{c}0.48 \pm \\
0.10^{\mathrm{abcd}}\end{array}$ & $\begin{array}{c}0.35^{ \pm} \\
.05^{\mathrm{d}}\end{array}$ \\
\hline
\end{tabular}

Data are mean \pm standard deviation. G1: control, G2: ascorbic acid, G3: silymarin, G4: valproic acid; G5: valproic acid+ ascorbic acid; G6: valproic acid+ silymarin; G7: valproic acid+ ascorbic acid+ silymarin; AST: aspartate transaminase, ALT: alanine transaminase; ALP: alkaline phosphatase .TP: total protein; Alb.: albumin; a: significant compared to the control (G1) group; b: significant compared to ascorbic acid (G2) group; c: significant compared to silymarin (G3) group; d: significant compared to valproic acid (G4) group.

Table (3): Effects of valproic acid, ascorbic acid, silymarin, and their combination, on liver oxidative markers of rats $(n=42)$.

\begin{tabular}{|c|c|c|c|c|c|c|c|}
\hline Parameters & $\begin{array}{c}\text { G1 } \\
(n=6)\end{array}$ & $\begin{array}{c}\mathbf{G 2} \\
(\mathrm{n}=6)\end{array}$ & $\begin{array}{c}\text { G3 } \\
(n=6)\end{array}$ & $\begin{array}{c}\mathbf{G 4} \\
(\mathrm{n}=6)\end{array}$ & $\begin{array}{c}\text { G5 } \\
(n=6)\end{array}$ & $\begin{array}{c}\text { G6 } \\
(\mathrm{n}=6)\end{array}$ & $\begin{array}{c}\mathbf{G 7} \\
(\mathrm{n}=6)\end{array}$ \\
\hline CAT (U/g tissue) & $\begin{array}{l}346.66 \pm \\
22.34\end{array}$ & $\begin{array}{l}349.16 \pm \\
20.75\end{array}$ & $\begin{array}{c}351.0 \pm \\
16.82\end{array}$ & $\begin{array}{l}209.1 \pm \\
14.07^{\mathrm{abc}}\end{array}$ & $\begin{array}{l}292.33 \pm \\
17.18^{\text {abcd }}\end{array}$ & $\begin{array}{l}295.83 \pm \\
15.49^{\text {abcd }}\end{array}$ & $\begin{array}{l}323.83 \pm \\
23.05^{\mathrm{d}}\end{array}$ \\
\hline SOD (U/g tissue) & $\begin{array}{c}291.33 \pm \\
4.36\end{array}$ & $\begin{array}{c}295.33 \pm \\
4.88\end{array}$ & $\begin{array}{c}297.17 \pm \\
5.31\end{array}$ & $\begin{array}{l}225.83 \pm \\
5.49^{\text {abc }}\end{array}$ & $\begin{array}{l}257.83 \pm \\
6.82^{\text {abcd }}\end{array}$ & $\begin{array}{l}262.66 \pm \\
6.12^{\text {abcd }}\end{array}$ & $\begin{array}{c}282.50 \pm \\
5.68^{\mathrm{d}}\end{array}$ \\
\hline GSH (mmol/g tissue) & $\begin{array}{c}6.44 \pm \\
0.36\end{array}$ & $\begin{array}{c}6.51 \pm \\
0.43\end{array}$ & $\begin{array}{c}6.67 \pm \\
0.38\end{array}$ & $\begin{array}{l}4.24 \pm \\
0.21^{\mathrm{abc}}\end{array}$ & $\begin{array}{c}5.10 \pm \\
0.44^{\mathrm{abcd}}\end{array}$ & $\begin{array}{c}5.38 \pm \\
0.31^{\text {abcd }}\end{array}$ & $\begin{array}{l}5.95 \pm \\
0.42^{d}\end{array}$ \\
\hline GPx (mmol/g tissue) & $\begin{array}{c}2.47 \pm \\
0.35 \\
\end{array}$ & $\begin{array}{c}2.51 \pm \\
0.29 \\
\end{array}$ & $\begin{array}{c}2.56 \pm \\
0.39 \\
\end{array}$ & $\begin{array}{l}1.30 \pm \\
0.18^{\text {abc }} \\
\end{array}$ & $\begin{array}{c}1.95 \pm \\
0.11^{\mathrm{abcd}}\end{array}$ & $\begin{array}{c}1.98 \pm \\
0.15^{\text {abcd }}\end{array}$ & $\begin{array}{l}2.21 \pm \\
0.29^{d} \\
\end{array}$ \\
\hline $\begin{array}{c}\text { MDA (mmol/g } \\
\text { tissue) }\end{array}$ & $\begin{array}{c}47.50 \pm \\
4.32\end{array}$ & $\begin{array}{c}44.83 \pm \\
4.07\end{array}$ & $\begin{array}{c}43.0 \pm \\
2.53\end{array}$ & $\begin{array}{l}85.50 \pm \\
3.62^{\mathrm{abc}}\end{array}$ & $\begin{array}{c}71.0 \pm \\
2.83^{\mathrm{abcd}}\end{array}$ & $\begin{array}{c}68.0 \pm \\
3.03^{\mathrm{abcd}}\end{array}$ & $\begin{array}{l}54.16 \pm \\
4.07^{\mathrm{bcd}}\end{array}$ \\
\hline
\end{tabular}

Data are mean \pm standard deviation. G1: control, G2: ascorbic acid, G3: silymarin, G4: valproic acid; G5: valproic acid+ ascorbic acid; G6: valproic acid+ silymarin; G7: valproic acid+ ascorbic acid+ silymarin; CAT: catalase, SOD: superoxide dismutase; GSH: glutathione. GPx: glutathione peroxidase; MDA: malondialdehyde; a: significant compared to the control (G1) group; b: significant compared to ascorbic acid (G2) group; c: significant compared to silymarin (G3) group; d: significant compared to valproic acid (G4) group. 


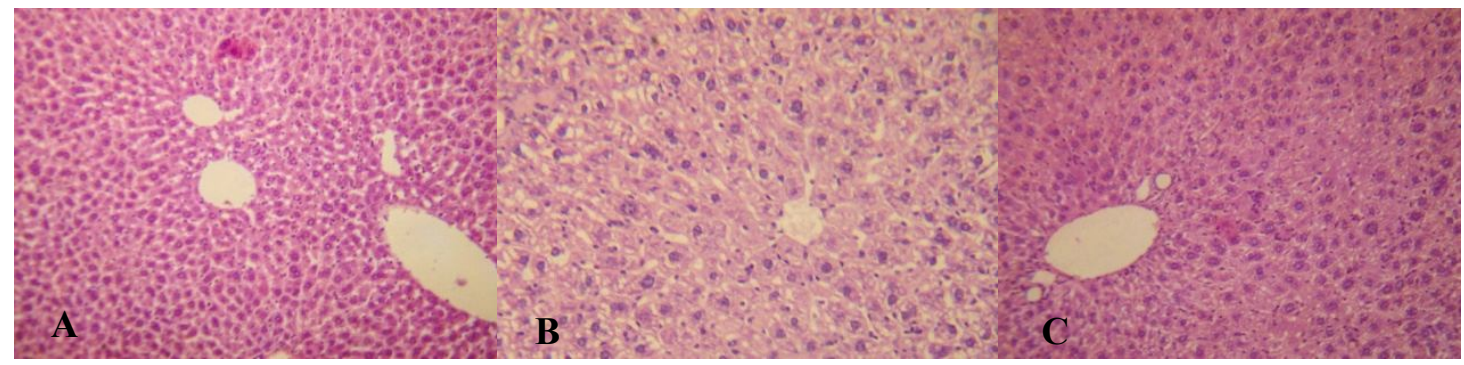

Fig. (1): Liver section of a negative control rat (A), silymarin(B) and ascorbic acid (C): showing normal hepatic architecture with the hepatic lobule formed of cords of hepatocytes, Kupffer cells, and sinusoids. (H\&E, X 400).

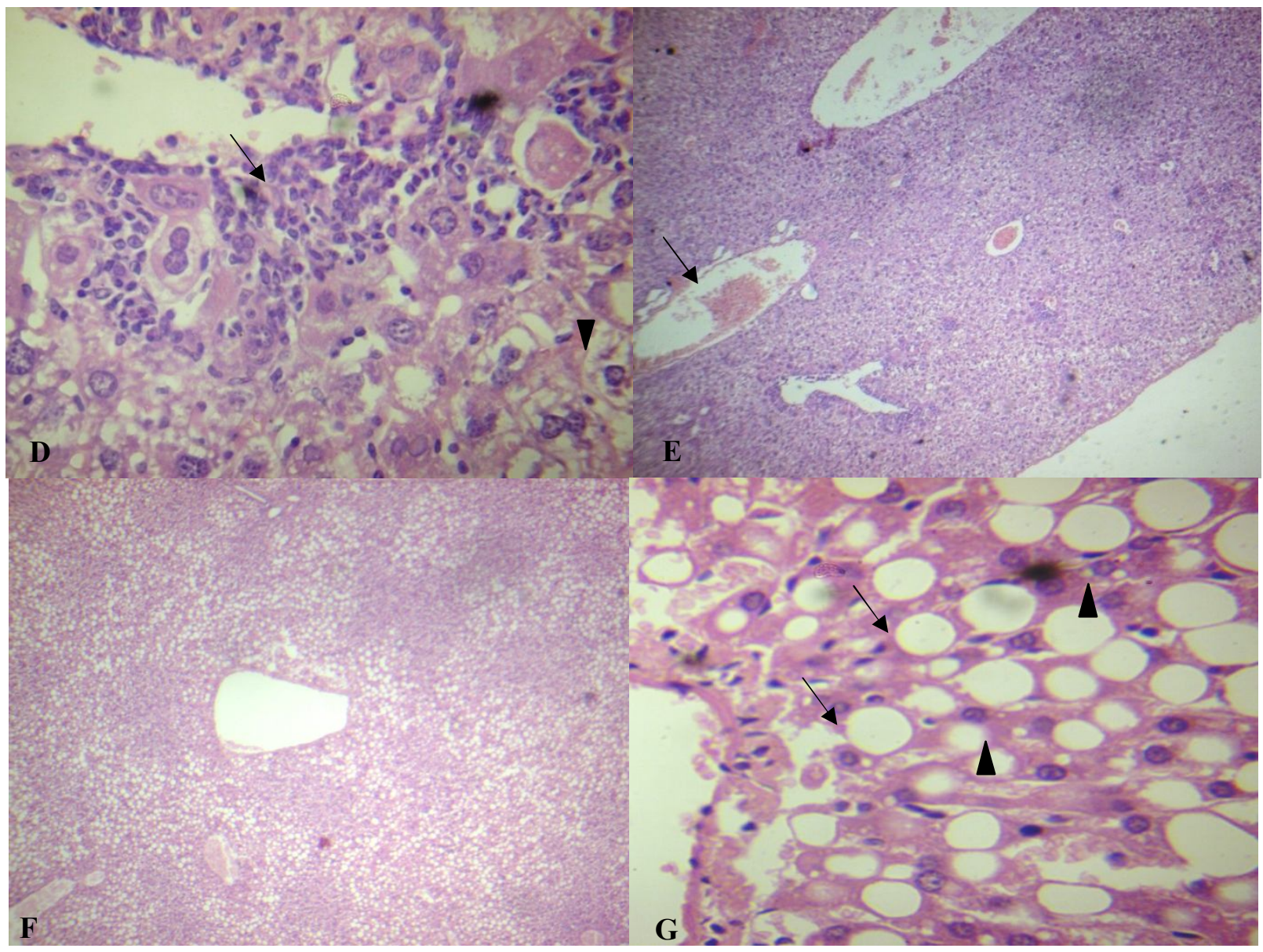

Fig. (2): Liver section from the valproic acid group shows:(D) loss of normal radiating pattern of hepatocytes with some hepatocytes showing increased eosinophilia and others undergoing degeneration (arrowhead). Mononuclear inflammatory cell infiltrate is also seen (arrow). Kupffer cells are increased in size (H \& E 400 $\mathrm{X}$ ). (E) Dilated and congested central veins (arrow) with disarray of hepatocytes (H\&E $100 \mathrm{X}$ ). (F) Liver sections show loss of normal hepatic architecture and accumulation of fat (hepatic steatosis) (H \& E $100 \mathrm{X}$ ). (G) Liver sections show the presence of microvesicular (arrowheads) and macrovesicular steatosis (arrows). (H \& $\mathrm{E} 400 \mathrm{X})$ 


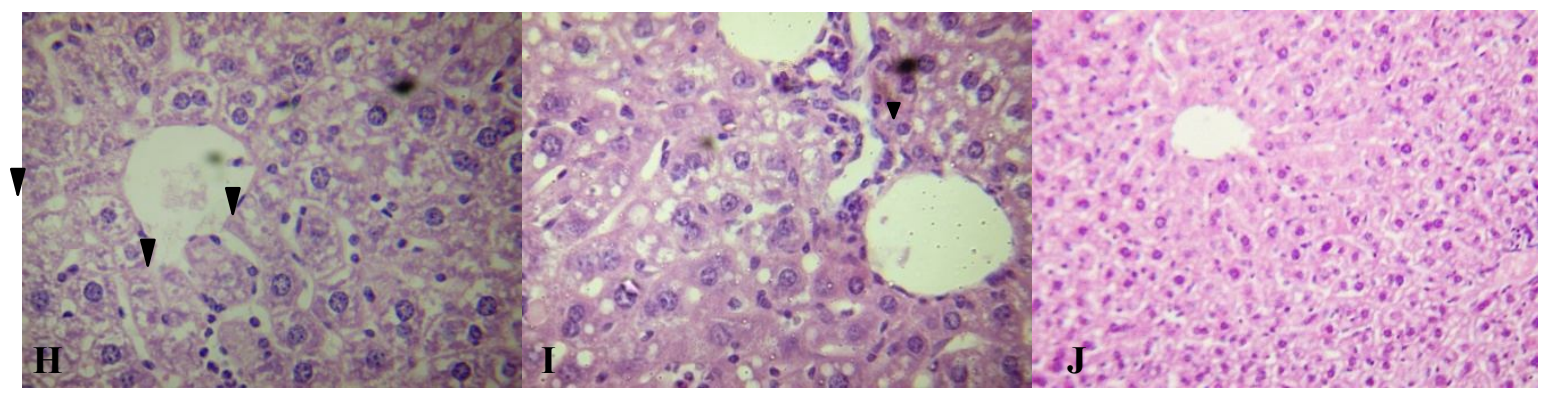

Fig. (3): (H) Liver sections from the group of valproic acid + ascorbic acid shows feathery degeneration of hepatocytes (arrowhead) with small area of inflammatory cells (H \& E $400 \mathrm{X}$ ). (I) Liver sections from the group of valproic acid + silymarin group shows near normal hepatic architecture. Few hepatocytes show degenerative changes (arrowhead). Inflammatory cells are few (H \& E $400 \mathrm{X})$. (J) Liver sections from the group of valproic acid + ascorbic acid + silymarin group shows normal histological structure of central vain (CV) and surrounding hepatocytes (H \& E $400 \mathrm{X})$.

\section{Discussion:}

Prolonged administration of VPA has been condemned for causing hepatic insult ranging from mild hepatotoxicity to severe hepatic failure even reaching to death. Oxidative stress has been strongly proposed as one of the mechanisms for VPA induced hepatotoxicity, where free radicals and reactive oxygenspecies (ROS) are released and lipid peroxidation occurs (Tonget al., 2005) leading to damage of DNA (Abdella et al., 2014)and apoptosis (Hamza et al., 2015) ending up with liver necrosis and cell death (Kiang et al., 2011). Toxic metabolites of VPA have also been condemned for VPA induced hepatotoxicity (Akula et al., 2016).

The present study was conducted to assess the hepatoprotective effect of silymarin, ascorbic acid and their combination in VPA induced hepatic toxicity in male albino rats.

The results showed that the rats which received VPA had a significant decrease in their bodyweights and the relative weights of the body while the rats which received ascorbic acid, silymarin alone and their combination with VPA showed a significant improvement in gaining weights. This finding was in agreement with other studies that found decreased body weights of rats with VPA administration (Wolden-Hanson et al., 1998; Schneider and Przewłocki, 2005).

The present study revealed significant elevation of liver enzymes AST, ALT, and ALP in the group administered VPA. These enzymes are markers of liver cell injury (Knapp et al., 2008). These results are in parallel with the results from other studies (Sokmen et al., 2012; Al-Rouby and Gawish, 2013; Abdel-Dayem et al., 2014; Cakmak and Yanardag, 2015; Hamzaet al., 2015). Bilirubin assesses the hepatocytes conjugation and excretory power and it was found to be significantly increased in the group administered VPA which supports the findings reported in other studies (Cakmak and Yanardag, 2015).

Valproic acid produced a significant decrease in albumin and protein; and this is in consistence with other studies (Abdel-Dayem et al., 2014; Hamzaet al., 2015). Depletion of ATP due to mitochondrial dysfunction induced by VPA leads to decreased protein formation as well as decreased gluconeogenesis (Hamzaet al., 2015).

Hepatotoxic metabolites of VPA are produced through oxidation by cytochrome P450. Those toxic metabolites then conjugate 
with reduced glutathione (GSH) as a protective detoxification mechanism leading to GSH consumption. Furthermore, cytochrome P450 2E1 action on VPA is associated with increased production of ROS and hence increased oxidative stress (Pourahmad et al., 2012; Hamzaet al., 2015). Pourahmad et al. (2012) found that inhibition of this coenzyme leads to protection against VPA induced cytotoxicity. As GSH is well known for its antioxidant activity by binding ROS, it gets consumed in case of oxidative stress produced by VPA administration as shown in the present study as well as in several previous studies (Gupta et al., 2004; Tong et al., 2005 Sokmen et al., 2012; Abdel-Dayem et al., 2014). Jurima-Romet et al. (1996) detected that glutathione depleted hepatocytes are more prone to VPA induced cytotoxicity.

In the present study, a significant decrease was detected in the antioxidant enzymes (SOD, CAT, GPx), associated with a significant increase in lipid peroxidation (elevation of MDA) with administration of VPA. This finding was reported in several studies (Vidya and Subramanian, 2006; Sokmen et al., 2012; Abdel-Dayem et al., 2014; Hamza et al., 2015). Pippenger et al. (1989) also detected the decrease in erythrocytes GPx and SOD in patients administered VPA for long periods. They related that to lack of trace elements "e.g. selenium, copper, and zinc" which are cofactors for SOD and GPx activities. They also emphasized that those enzymes become over activated and saturated with VPA induced oxidative stress ending up with cell injury. Zhang et al. (2011) reported a significant decline in SOD and CAT enzymes activities associated with an increase in the level of MDA in neutrophils of patients treated with VPA. These results are contradicting the results of Seçkin et al. (1999) who reported non-significant alterations in antioxidant enzymes or in the level of MDA. However, this contradiction might be explained by the different dose and duration of administration of VPA in Seçkin et al. (1999) study; as they administered divided doses for shorter duration (400 mg/kg divided into 2 doses /day for 10 days)

In the present study, various histopathologic changes were observed in rats' livers after administration of VPA in the form of inflammatory infiltration, hepatocytes degeneration, enlarged Kupffer cells and central vein dilatation. Those changes were reported in other studies (Jassim, 2013; Abdella et al., 2014). In addition to these changes, fatty infiltration (micro and macrovesicular steatosis) was detected in liver sections which is consistent with findings from other studies (Tong et al., 2005; Al-Rouby and Gawish, 2013; Abdel-Dayem et al., 2014; Hamza et al., 2015). As a consequence of these changes, a significant increase in livers' weights in VPA group was detected; which was also reported by Abdel-Dayem et al. (2014).

Mitochondrial injury and dysfunction as a result oxidative stress has been proposed as a mechanism for VPA induced hepatotoxicity. Hamza et al. (2015) detected decreased production of ATP in rats intoxicated with VPA. The inability of mitochondria to synthesize ATP leads to acidosis and osmotic injury that ends up with lysis of hepatocyte plasma membrane. Furthermore, ROS and lipid peroxidation products (LPO) produced by VPA induce lysosomal membrane injury leading to proteolysis and stimulation of autophagic process ending up with hepatocytes degeneration and necrosis. Hence, protective agents that inhibit or lessen oxidative stress "antioxidants and radical scavengers" protect hepatocytes against VPA induced toxicity (Pourahmad et al., 2012).

Fatty infiltration (steatosis) found in the current study has been proposed to be due to inhibition of some enzymes in $\beta$-oxidation 
cycle by VPA and its metabolites. This leads to interference with oxidation of fatty acids ending up with accumulation of lipids inside hepatocytes (Akulaet al., 2016). Abdel-Dayem et al. (2014) detected that VPA increased the release of "tumor necrosis factor-alpha" $(\mathrm{TNF} \times)$ which provokes the inflammatory reaction (noticed in the present study). This factor leads to down regulation of "peroxisome proliferator-activated receptor- $\alpha$ " (PPAR $\alpha)$ which is responsible for fatty acids oxidation (FAO), leading to accumulation of fatty acids inside the cells. Additionally, VPA prolonged administration causes mobilization of fatty acids from their stores to the liver (Akula et al. 2016). Mitochondrial injury caused by VPA also interferes with continuous release of calcium from its stores which might affect secretion and movement of the vesicles leading to steatosis due to inability of cells to get rid of lipids inside them (Bellringer et al., 1988). Enlarged Kupffer cells observed with VPA administration might be explained by both the accumulation of lipids and glycogen in their cytoplasm as explained by Al-Rouby and Gawish (2013). It might also be explained by the depletion of ATP, acidosis and consequent osmotic injury (Pourahmad et al., 2012). Vascular dilation was suggested to be a response to hypoxia and loss of ATP induced by VPA (Abdella et al., 2014).

In the present study, each of ascorbic acid and silymarin showed hepatoprotective effects due to their antioxidant properties; however they did not improve the condition completely. This might be related to the severe oxidative stress induced by VPA. They might have produced complete recovery if given with larger doses, for longer duration or if given prior to VPA administration to stimulate the antioxidant system. However, when they were combined together, the hepatoprotective effect was the maximum. This enhanced effect emerged from their synergistic antioxidant properties, which could face and ameliorate the oxidative stress induced by VPA.

Ascorbic acid is recognized for its antioxidant properties. It acts as an electron donor, which makes it a vigorous ROS scavenger that inhibits lipid peroxidation (Xavier et al., 2007). It was reported to ameliorate the hepatotoxic effect of many chemicals and drugs. It was able to decrease liver enzymes (ALT, AST and ALP) as well as MDA to near normal levels. It has also been able to improve GSH and antioxidant enzymes based on its antioxidant properties (Adikwu and Deo, 2013). Amel et al. (2012) reported the protective effect of ascorbic acid against VPA induced teratogenicity. They found that the group administered ascorbic acid + VPA showed a significant decrease in LPO products (e.g. MDA). Jurima-Romet et al. (1996) reported the protective role of ascorbic acid in hepatic injury induced by "4-ene VPA" in glutathione depleted hepatocytes and its effect when combined with vitamin E. Surprisingly, none of them had any effect on GSH levels, furthermore, they showed no synergistic effect in protecting hepatocytes.

Silymarin is a flavonoid with antioxidant properties. It acts as a free radical scavenger that protects hepatocytes against lipid peroxidation leading to stabilization of the membranes of hepatocytes (Najafzadeh et al., 2010). It has also been reported to improve liver functions in carbon tetrachloride induced hepatotoxicity (Yadav et al., 2008). It was able also to improve the levels of GSH and antioxidant enzymes (SOD and CAT) as well as inhibiting lipid peroxidation products in hepatotoxicity induced by arsenic (Jain et al., 2011). Silybin; a major constituent of silymarin has been shown to decrease ALT, AST, as well as MDA and increase GSH and SOD levels. This was related to its ability to inhibit oxidative stress, to stabilize mitochondrial membrane and to inhibit insulin resistance (Yao et al., 2011). 
The hepatoprotective effect of both silymarin and ascorbic acid on myoglobinuric liver in rats was assessed in Sabzevarizadeh and Najafzadeh study (2012) where ascorbic acid and the combination of ascorbic acid and silymarin lowered the liver enzymes significantly and improved histopathological findings. However, silymarin alone did not show any hepatoprotective effect; authors related that to the solvent used for silymarin (ethanol) (Sabzevarizadeh and Najafzadeh, 2012). This combination could also ameliorate the hepatotoxic effect due to acute lead toxicity (Shalana et al., 2005).

Sabiu et al. (2015) reported the ability of each of ascorbic acid and silymarin to reduce the levels of liver enzymes (ALT, AST and ALP) and bilirubin, and to increase GSH, antioxidant enzymes (SOD, CAT and GPx) and protein levels in rats administered hepatotoxic doses of acetaminophen. They could also ameliorate the hepatotoxic histological changes in those rats. When combined together, a remarkable improvement in all measured parameters was detected suggesting the power of their synergistic antioxidant effect.

\section{Conclusion:}

The present study concluded that hepatotoxicity induced by VPA was associated with oxidative stress. Each of ascorbic acid and silymarin could decrease the hepatotoxic effect of VPA through their antioxidant properties. When they were combined together, maximum improvement of liver functions, oxidative markers and histopathologic changes was achieved.

\section{Conflict of interest}

The researchers declare no conflicts of interest.

\section{References :}

Abdel-Dayem, MA; Elmarakby, AA; AbdelAziz, AA et al. (2014):"Valproateinduced liver injury: modulation by the omega-3 fatty acid DHA proposes a novel anticonvulsant regimen". Drugs in $\mathrm{R}$ and $\mathrm{D}, 14(2): 85-94$.

Abdella, EM; Galaly, SR; Mohammed, HM; Khadrawy, SM. (2014): "Protective role of vitamin $\mathrm{E}$ against valproic acid-induced cytogenotoxicity and hepatotoxicity in mice". The Journal of Basic and Applied Zoology, 67(4):127-139.

Adikwu, E; Deo, O. (2013): "Hepatoprotective effect of vitamin $\mathrm{C}$ (ascorbic acid)". Pharmacology and Pharmacy, 4(1):84-92.

Aebi, H (1984):"Catalase in vitro". Methods in Enzymology, 105:121-126.

Akula, B; Uduman, MSTS; Chakka, G. (2016): "A comprehensive review on valproic acid induced liver injury". International Journal of Review of Life and Sciences, 6(1):1-4.

Al-Rouby, N; Gawish, S. (2013): "Histological study on the possible protective effect of nigella sativa oil on experimentally induced hepatotoxicity in albino rats treated with sodium valproate". Global Advanced Research Journal of Medicine and Medical Sciences, 2(4):90-99.

Amel, A; Djamila, Z; Nassima, B; et al. (2012): "The protective effect of Chrysanthemum fantanesii extract, vitamin $\mathrm{E}$ and $\mathrm{C}$ on sodium valproateinduced embryotoxicity in pregnant mice". Journal of Medicinal Plants Research, 6(19):35-44.

Amrani, A; Benaissa, O; Boubekri, N; et al. (2016): "Impact of Chrysanthemum fontanesii extract on sodium valproate mediated oxidative damage in mice 
kidney". Journal of Applied Pharmaceutical Science, 6(4):67-71.

Bancroft, J; Stevens, A; Turner, D. (1996): "Theory and practice of histological techniques". 4th Ed Churchill Living Stone, New York Edinburgh. Madrid, Sanfrancisco.

Bektur, NE; Sahin, E; Baycu, C; Unver, G. (2016): "Protective effects of silymarin against acetaminophen-induced hepatotoxicity and nephrotoxicity in mice". Toxicology and Industrial Health, 32(4):589-600.

Bellringer, ME; Rahman, K; Coleman, R. (1988): "Sodium valproate inhibits the movement of secretory vesicles in rat hepatocytes". Biochemical Journal, 249(2):513-519.

Bessey, OA; Lowky, O; Brock, MJ. (1946): "A method for the rapid determination of alkaline phosphatase with five cubic millimeters of serum". Journal of Biological Chemistry, 164:321-329.

Beutler, E; Duron, O; Kelly, BM. (1963): "Improved method for the determination of blood glutathione". Journal of Laboratory and Clinical Medicine, 61:882-888.

Cakmak, NH; Yanardag, R. (2015): "Edaravone, a free radical scavenger, protects liver against valproic acid induced toxicity". Journal of the Serbian Chemical Society, 80(5):627637.

El-Kamary, SS; Shardell, MD; AbdelHamid, MI et al. (2009): "A randomized controlled trial to assess the safety and efficacy of silymarin on symptoms, signs and biomarkers of acute hepatitis". Phytomedicine, 16(5):391-400.

Ergul, Y; Erkan, T; Uzun, H; et al. (2010): "Effect of vitamin $\mathrm{C}$ on oxidative liver injury due to isoniazid in rats". Pediatrics International, 52(1):69-74.
Fernandez-Botran, R; Gorantla, V; Sun, X; et al. (2002): "Targeting of glycosaminoglycan-cytokine interactions as a novel therapeutic approach in allotransplantation1". Transplantation, 74(5):623-629.

Girish, C; Koner, BC; Jayanthi, S; et al. (2009): "Hepatoprotective activity of picroliv, curcumin and ellagic acid compared to silymarin on paracetamol induced liver toxicity in mice". Fundamental and Clinical Pharmacology, 23(6):735-745.

Gupta, M; Gupta, YK; Agarwal, $S$ et al. (2004): "A randomized, double-blind, placebo controlled trial of melatonin add-on therapy in epileptic children on valproate monotherapy: effect on glutathione peroxidase and glutathione reductase enzymes". British Journal of Clinical Pharmacology, 58(5):542-547.

Hamza, AA;El Hodairy, F; Badawi, AM. (2015): "Safranal ameliorates Sodium Valproate-induced liver toxicity in rats by targeting gene expression, oxidative stress and apoptosis". Journal of Biomedical and Pharmaceutical Research, 4(6):46-60.

Jain, A; Yadav, A; Bozhkov, A et al. (2011): "Therapeutic efficacy of silymarin and naringenin in reducing arsenic-induced hepatic damage in young rats". Ecotoxicology and Environmental Safety, 74(4):607-614.

Jassim, AM. (2013): "Protective Effect of Petroselinum crispum (parsley) extract on histopathological changes in liver, kidney and pancreas induced by Sodium Valproate-In male Rats". مجلة Kufa Journal For Veterinary Medical Sciences, 4(1):20-27.

Jurima-Romet, M; Abbott, FS; Tang, W; Huang, HS. (1996): "Cytotoxicity of unsaturated metabolites of valproic 
acid and protection by vitamins $\mathrm{C}$ and $\mathrm{E}$ in glutathione-depleted rat hepatocytes". Toxicology, 112(1):6985.

Kaur, M;Agarwal, R, (2007): "Silymarin and epithelial cancer chemoprevention: how close we are to bedside?" Toxicology and Applied Pharmacology, 224(3):350-359.

Kei, S. (1978): "Serum lipid peroxide in cerebrovascular disorders determined by a new colorimetric method". Clinica Chimica Acta, 90(1):37-43.

Kesterson, JW; Granneman, GR; Machinist, JM. (1984): "The hepatotoxicity of valproic acid and its metabolites in rats. I. Toxicologic, biochemical and histopathologic studies". Hepatology, 4(6):1143-1152.

Khan, S; Ahmad, T; Parekh, CV et al. (2011): "Investigation on sodium valproate induced germ cell damage, oxidative stress and genotoxicity in male Swiss mice". Reproductive Toxicology, 32(4):385-394.

Kiang, TK; Teng, XW; Karagiozov, $S$ et al. (2010): "Role of oxidative metabolism in the effect of valproic acid on markers of cell viability, necrosis, and oxidative stress in sandwich-cultured rat hepatocytes". Toxicological Sciences, 118(2):501-509.

Kiang, TK; Teng, XW; Surendradoss, $J$ et al. (2011): "Glutathione depletion by valproic acid in sandwich-cultured rat hepatocytes: Role of biotransformation and temporal relationship with onset of toxicity". Toxicology and Applied Pharmacology, 252(3):318-324.

Kingsley, GR. (1942): "The direct biuret method for the determination of serum proteins as applied to photoelectric and visual colorimetry". Journal of Laboratory and Clinical Medicine, 27:840-845.
Knapp, AC; Todesco, L; Beier, $K$ et al. (2008): "Toxicity of valproic acid in mice with decreased plasma and tissue carnitine stores". Journal of Pharmacology and Experimental Therapeutics, 324(2):568-575.

Lawrence, RA; Burk, RF. (1976): "Glutathione peroxidase activity in selenium-deficient rat liver". Biochemical and Biophysical Research Communications, 71(4):952-958.

Lowry, OH; Rosebrough, NJ, Farr, AL; Randall, RJ. (1951): "Protein measurement with the Folin phenol reagent". Journal of Biological Chemistry, 193(1):265-275.

Minami, M; Yoshikawa, H. (1979): "A simplified assay method of superoxide dismutase activity for clinical use". Clinica Chimica Acta, 92(3):337-342.

Najafzadeh, H; Jalali, MR; Morovvati, H; Taravati, F. (2010):"Comparison of the prophylactic effect of silymarin and deferoxamine on iron overload-induced hepatotoxicity in rat". Journal of Medical Toxicology, 6(1):22-26.

Perry, B; Doumas, B; Buffone, $G$ et al. (1986):"Measurement of total bilirubin by use of bilirubin oxidase". Clinical Chemistry, 32(2):329-332.

Perucca, E. (2002): "Pharmacological and therapeutic properties of valproate". CNS Drugs, 16(10):695-714.

Pinnell, AE; Northam, BE. (1978): "New automated dye-binding method for serum albumin determination with bromcresol purple". Clinical Chemistry, 24(1):80-86.

Pippenger, C; Meng X; Von- Lente F et al. (1989): "Valproate therapy suppresses GSH. PX and SOD enzyme activity. A possible mechanism for VPA induced idiosyncratic drug toxicity". Clinical Chemistry, 35:1173-1177. 
Pourahmad, J; Eskandari, MR; Kaghazi, A et al. (2012): "A new approach on valproic acid induced hepatotoxicity: involvement of lysosomal membrane leakiness and cellular proteolysis". Toxicology in Vitro, 26(4):545-551.

Reitman, S; Frankel, S. (1957): "A colorimetric method for the determination of serum glutamic oxalacetic and glutamic pyruvic transaminases". American Journal of Clinical Pathology, 28(1):56-63.

Rosenberg, G. (2007): "The mechanisms of action of valproate in neuropsychiatric disorders: can we see the forest for the trees?" Cellular and Molecular Life Sciences, 64(16):2090-2103.

Sabiu, S; Sunmonu, TO; Ajani, EO; Ajiboye, TO. (2015): "Combined administration of silymarin and vitamin C stalls acetaminophen-mediated hepatic oxidative insults in Wistar rats". Revista Brasileira de Farmacognosia, 25(1):29-34.

Sabzevarizadeh, M; Najafzadeh, H. (2012): "Comparison effect of silymarin and vitamin $\mathrm{C}$ on liver function in myoglobinuric status in rats". World Applied Sciences Journal, 17 (2): 228232.

Schneider, T; Przewłocki, R. (2005): "Behavioral alterations in rats prenatally exposed to valproic acid: animal model of autism". Neuropsychopharmacology, 30(1):80-89.

Seçkin, Ş; Başaran-Küçükgergin, C; Uysal, M. (1999):"Effect of acute and chronic administration of sodium valproate on lipid peroxidation and antioxidant system in rat liver". Basic and Clinical Pharmacology and Toxicology, 85(2):294-298.

Shalana, MG; Mostafa, MS; Hassouna MM. (2005): "Amelioration of lead toxicity on rat liver with vitamin $\mathrm{C}$ and silymarin supplements," Toxicology, 206:1-15.

Silva, M; Aires, C; Luis, $P$ et al. (2008). "Valproic acid metabolism and its effects on mitochondrial fatty acid oxidation: a review". Journal of Inherited Metabolic Disease, 31(2):205-216.

Sokmen, BB; Tunali, S; Yanardag, R. (2012): "Effects of vitamin U (Smethyl methionine sulphonium chloride) on valproic acid induced liver injury in rats". Food and Chemical Toxicology, 50(10):3562-3566.

Stangeland, T; Remberg, SF; Lye, KA. (2009): "Total antioxidant activity in 35 Ugandan fruits and vegetables". Food Chemistry, 113(1):85-91.

Tong, V; Teng, XW; Chang, TK; Abbott, FS. (2005): "Valproic acid I: time course of lipid peroxidation biomarkers, liver toxicity, and valproic acid metabolite levels in rats". Toxicological Sciences, 86(2):427-435.

Tung, EW; Winn, L. (2011): "Valproic acid increases formation of reactive oxygen species and induces apoptosis in postimplantation embryos: A role for oxidative stress in valproic acidinduced neural tube defects". Molecular Pharmacology, 80:979-987.

Vidya, M; Subramanian, P. (2006): "Effects of a-ketoglutarate on antioxidants and lipid peroxidation products in rats treated with sodium valproate". Journal of Applied Biomedicine, 4:141-146.

Wolden-Hanson, T; Gidal, BE; Atkinson, RL. (1998): "Evaluation of a rat model of valproate-induced obesity". Pharmacotherapy: The Journal of Human Pharmacology and Drug Therapy, 18(5):1075-1081.

Wu, W; Su, M; Li, T et al.(2015): "Cantharidin-induced liver injuries in mice and the protective effect of 
vitamin $\quad \mathrm{C} \quad$ supplementation". International Immunopharmacology, 28(1):182-187.

Xavier, S; Barbosa, C; Barros, D et al. (2007): "Vitamin C antioxidant effects in hippocampus of adult Wistar rats after seizures and status epilepticus induced by pilocarpine". Neuroscience Letters, 420(1):76-79.

Yadav, NP; Pal, A; Shanker, K et al. (2008):

"Synergistic effect of silymarin and standardized extract of Phyllanthus amarus against $\mathrm{CCl}$ 4-induced hepatotoxicity in Rattus norvegicus". Phytomedicine, 15(12):1053-1061.

Yao, J; Zhi, M; Minhu, C. (2011): "Effect of silybin on high-fat-induced fatty liver in rats". Brazilian Journal of Medical and Biological Research, 44(7): 652659.

Zhang, Y; Zhang, M; Wang, X et al. (2011): "Effects of sodium valproate on neutrophils' oxidative metabolism and oxidant status in children with idiopathic epilepsy". Zhonghua Er Ke Za Zhi. Chinese Journal of Pediatrics, 49(10):776-781. 


\section{التأثيرالوقائي للسليمارين وحامض الأسكوربيك في التسمم الكبدي الناجم

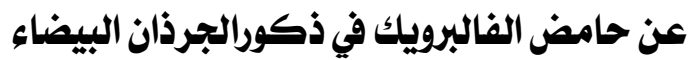

\section{محروس عبد الباسط إبراهييم'، ، رحاب إبراهيم عبدالكريه'، هاني جودة تقام'،

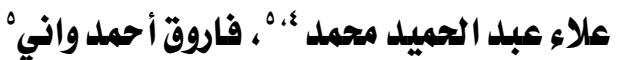

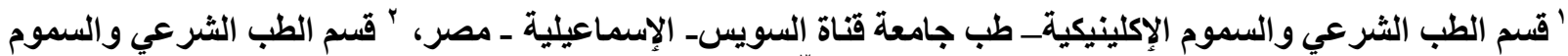

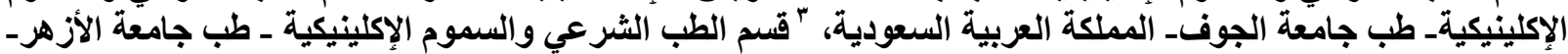

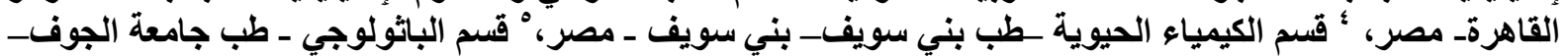
المملكة العربية السعودية.

يستخدم حـامض الفالبرويـك اسـتخدامًا واسـعًا في جميـع أنحـاء العـالم لعـلاج مـرض الصرع، و الـصداع النصفي، كما يستخدم كعقار للاستقر ار المز اجي في بعض الأمر اض النفسية. وقد تمت إدانـة هذا العقار لتسببه

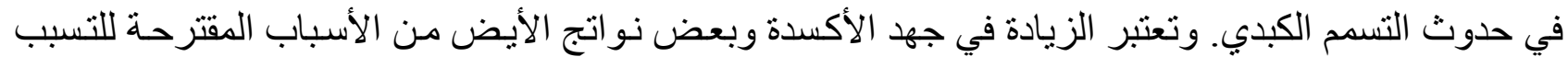

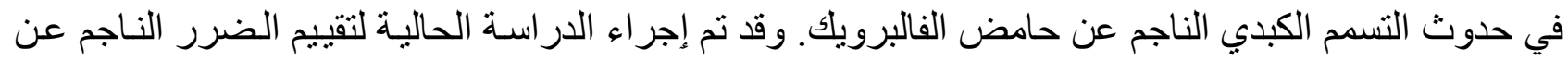
استخدام جر عـات سـامة مـن عقار حـامض الفالبرويلك على الكبـد، وكذلك إلى تقيهم الدور الوقائي للسليمارين وحامض الأسكوربيك في حالات التسمم الكبدي الناجم عن عقار الفالبرويك. وفي هذه الدر اسة تم تقسيم عدد بـ

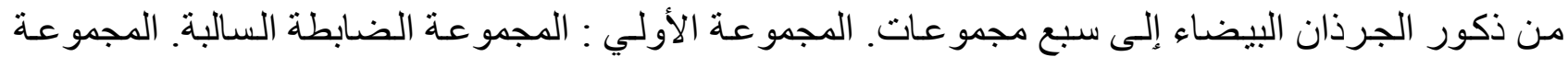

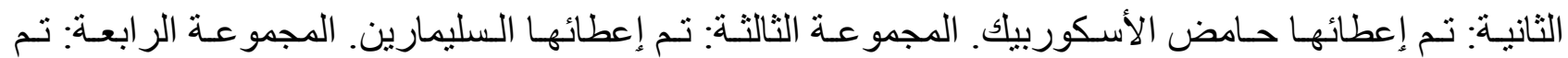
إعطائهـا حـامض الفالبرويــك. المجمو عـة الخامسسة: حسامض الفالبرويـك + حـامض الأسـكوربيك. المجموعـة السادسة: حسامض الفالبرويك + السليمارين. المجوعـة السابعة: حـامض الفالبرويلك + حـامض الأسكوربيك + السليمارين. وقد تمت التضحية بالفئر ان بعد أربعة أسابيع من العلاج، وتم استخر اج الكبد لعمل فحص الأنسجة،

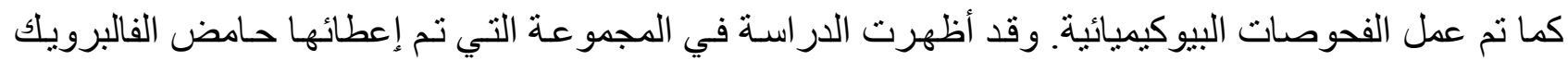

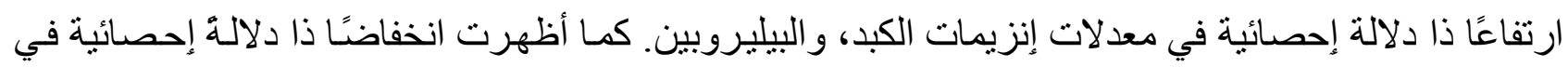

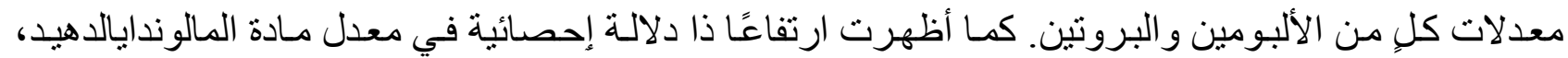
و انخفاضًا ذا دلالة إحصائية في معدلات إنزيمات مضادات الأكسدة. وقد أظهر فحص شر ائح الكبد فقد النمط

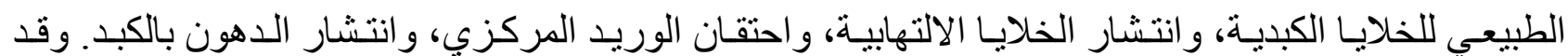

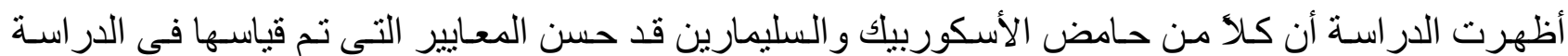
بصورة جزئية، بينما عندما تم إعطائهما معا تم حدوث تحسن كامل في معظم المعابير التي تم قياسـها بالدر اسـة،

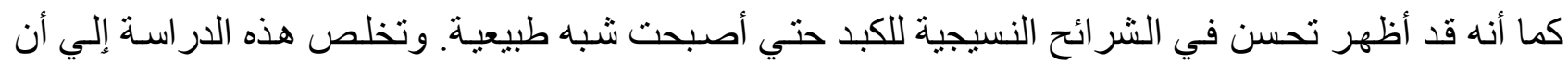
إعطاء حامض الفالبرويك بجر عات سامة يتسبب في حدوت تسمح بالكبد وزيادة في جهد الأكسدة. كما أن الدمج بين حامض الأسكوربيك و السليمارين معا له تأثير وقائي مضاعف مضاد للأكسدة ويوفر أقصى حماية للكبد. 